ROCZNIKI NAUK PRAWNYCH

Tom XXX, numer $2-2020$

DOI: https://doi.org/10.18290/rnp20302-12

\title{
ZAGADNIENIA WYBRANE Z PROCESU BEATYFIKACYJNEGO PAWŁA YUN JI-CHUNGA I JEGO 123 TOWARZYSZY
}

\begin{abstract}
WSTĘP
„Wspólnota unikalna w dziejach Kościoła”, założona wyłącznie przez ludzi świeckich, zrodziła się pod koniec XVIII wieku na ziemi Korei. Wierni świeccy przez ciekawość intelektualną poznali Chrystusa dzięki księgom przywiezionym z Chin. Jeden z nich w 1784 r. udał się do Pekinu i tam został ochrzczony. Wróciwszy, głosił Ewangelię wśród Koreańczyków i w ten sposób: „Ten świeżo powstały Kościół, tak młody, a już tak silny w swej wierze, przetrwał kolejne fale okrutnych prześladowań. I tak w ciągu niespełna stu lat mógł już poszczycić się około dziesięciu tysiącami męczenników"1.
\end{abstract}

Dr hab. LidIA FIEJDASZ-BUCZEK - adiunkt, Katedra Historii, Norm Ogólnych, Prawa Sakramentów i Instytutów Życia Konsekrowanego, Instytut Prawa Kanonicznego, Wydział Prawa, Prawa Kanonicznego i Administracji Katolickiego Uniwersytetu Lubelskiego Jana Pawła II, Al. Racławickie 14, 20-950 Lublin; e-mail: lidia.fiejdasz-buczek@kul.pl; ORCID: https://orcid.org/ 0000-0001-6252-4027

${ }^{1}$ IoAnnes Paulus II, Seuli, ob decretos Coreanis martyribus Sanctorum caelitum honores (6.051984), AAS 76 (1984) 990-994; JAN PAWEŁ II, Śmierć Męczenników stała się początkiem nowego życia. 6 maja. Homilia podczas Mszy św. na placu Yovido w Seulu, w czasie której Ojciec Święty dokonat aktu kanonizacji 103 Btogosławionych Męczenników Koreańskich, [w:] Wielkie doświadczenie Kościoła w Azji i Oceanii. 21 podróż apostolska: Korea, Papua Nowa Gwinea, Wyspy Salomona, Tajlandia, 2-11 maj 1984, Warszawa: Verbinum Wydawnictwo Księży Werbistów 1986, s. 52. Ważniejsze źródła archiwalne i literaturę dotyczącą Kościoła katolickiego w Korei z lat 1789-2010 zamieszczono w aktach sprawy beatyfikacyjnej, zob.: Sources and bibliography, [w:] CONGRegatio De CAUsis SANCTORUM, Masanensis et Aliarum. Beatificationis seu Declarationis Martyrii Servorum Dei Pauli Yun Ji-chung. Christifidelis Laici et CXXIII Sociorum in odium fidei, uti fertur, interfectorum (†1791-1888), Positio super martyrio, Roma: Tipografia Nova Res s.r.1. 2013 [dalej: Positio], s. 52-77. Nowsza literatura zob.: Come in cielo, 
Beatyfikacja Pawła Yun Ji-chunga i 123 Towarzyszy, której dokonał Franciszek 16 sierpnia 2014 r. przy Bramie Gwanghwamum w Seulu, zgromadziła blisko milion wiernych ${ }^{2}$. Do heroicznego świadectwa wiary męczenników nawiązywało hasło VI Azjatyckich Dni Młodzieży ${ }^{3}$, a trasa papieskiej pielgrzymki wiodła przez miejsca naznaczone krwią męczenników. Uroczyście i wielopłaszczyznowo obchodzono rok poświęcony pamięci Męczenników (2016-2017), zainaugurowany przez arcybiskupa Seulu kard. Andrzeja Yeom Soo-junga dla uczczenia 150. rocznicy rozpoczęcia ostatniej fali antychrześcijańskich prześladowań Byeong-in (1866-1868)4 Dnia 22 lutego 2017 r. otwarto dwa procesy beatyfikacyjne łącznie 214 Męczenników koreańskich. Pierwszy dotyczy osób zamordowanych w czasie panowania dynastii Yi, drugi - umęczonych podczas prześladowań $\mathrm{w} X \mathrm{X}$ wieku'

Celem artykułu jest charakterystyka wybranych zagadnień z procesu beatyfikacyjnego pierwszych męczenników Kościoła katolickiego w Korei, począwszy od przedstawienia grupy Męczenników, cenzurę teologiczną ich pism, po wybór forum sądowego. Z racji geograficznych i kulturowych interesująca jest intencja tyrana (odium fidei) oraz sposoby zadawania śmierci. Ukazany zostanie także walor eklezjalny sprawy.

\section{KSZTAŁTOWANIE SIĘ GRONA 124 MECZENNIKÓW}

Sprawa Męczenników koreańskich zgładzonych w latach 1791-1888, podczas kilkunastu fal brutalnych prześladowań ${ }^{6}$, zgodnie $\mathrm{z}$ terminologią prawa kanonizacyjnego jest sprawą dawną. W myśl nr. 7 (in fine) Normae servandae z 7 lutego 1983 r. sprawa nazywa się dawną, „gdy środki dowodowe na temat męczeństwa [...] mogą być wydobyte tylko ze źródeł

così in terra: Seul e i 230 anni della Chiesa Cattolica in Corea Seoul, Seoul: Archdiocese of Seoul: Seoul Museum of History 2017.

${ }^{2}$ Szerzej: V. Faccioli Pintozzi, Giovani e martiri in Asia: la missione di Papa Francesco in Corea, prefazione di Pietro Parolin, Siena: Edizioni Cantagalli 2014.

3 „Młodzieży Azji! Powstań! Chwała męczenników jaśnieje nad Tobą”. Franciscus, Occasione Eucharisticae celebrationis in exitu VI Diei Asiaticae Iuventutis apud castellum urbis vulgo Haemi in Corea (17.08.2014), AAS 106 (2014) 686-688.

${ }^{4}$ H. KIm HeE-Joong, On the Occasion of the 150th Anniversary of the Martyrdom during the Byeong-in Persecution, "Catholic Bishops' Conference of Korea. Newsletter" 23(2016), nr 1, s. 6 [dalej: "CBCK Newsletter"]; Pastoral Letter on the Occasion of the 150th Anniversary of the Martyrdom during the Byeong-in Persecution, "CBCK Newsletter" 23(2016), nr 2, s. 6-7.

${ }^{5}$ News from the Church in Korea. Opening of the Tribunal Sessions towards the Beatification of 214 Korean Martyrs, "CBCK Newsletter" 24(2017), nr 1, s. 7.

${ }^{6}$ General introduction. Brief profile of the servants of God, [w:] Positio, s. 1. 
pisanych"7. Dlatego męczeństwo Pawła Yun Ji-chunga (1759-1791) i jego towarzyszy - „ojców założycieli” Kościoła katolickiego w Korei i wychowawców kolejnych pokoleń męczenników ${ }^{8}-$ mogło być udowodnione na podstawie dokumentów źródłowych. Należy podkreślić fakt, że wierni z klasy niższej nie mieli wystarczającego przygotowania do tego, aby dokumentować akty męczeństwa. Sytuacja zmieniła się po przybyciu do Korei w 1836 r. francuskich misjonarzy. Zadanie to, na wyraźne polecenia Szymona Berneux (1814-1866) - czwartego wikariusza apostolskiego w Korei, podjął w szczególności w latach 1858-1860 biskup pomocniczy i piąty wikariusz apostolski Korei Antoni Daveluy (1818-1866) 9 .

Myśl o rozpoczęciu procesu beatyfikacyjnego pierwszych męczenników zrodziła się jeszcze przed kanonizacją Andrzeja Kima Tae-gŏna, Pawła Chŏng Ha-sanga i 101 Towarzyszy (†1839-1868), której dokonał Jan Paweł II dnia 6 maja 1984 r. w Seulu. Dyskusja została jednak czasowo wstrzymana z powodu możliwego konfliktu ze sprawą 103 Męczenników. Po ich kanonizacji powstało wiele inicjatyw wspierających działania na rzecz beatyfikacji i kanonizacji pierwszych męczenników Korei oraz innych. Między innymi bp Angelo Kim Nam-su, Przewodniczący Komitetu Upamiętniającego 200-lecie Narodzin Kościoła Katolickiego w Korei, 24 czerwca 1984 r. wydał deklarację, w której pytał o możliwość wsparcia beatyfikacji 98 Męczenników, wśród których znajdowali się Ojcowie założyciele Kościoła - Jan Chrzciciel Yi-Byeok i jego towarzysze męczennicy oraz inni wyznawcy. Kiedy 31 grudnia 1984 r. Komitet został rozwiązany, zadanie to przekazano Komisji Liturgicznej Konferencji Episkopatu Korei. Z kolei diecezja Jeonju przywiązała wagę do beatyfikacji Pawła Yun Ji-chunga (1759-1791) i 4 Towarzyszy i już 12 kwietnia 1989 r. - zgodnie z dyspozycją normy nr 15c Normae servandae - otrzymała nihil obstat (Prot. N. 1664-1/89) ${ }^{10}$ Kongregacji. W 1996 r. diecezja Suwon zgłosiła Kongregacji zamiar wszczęcia procesu beatyfikacyjnego Pawła Yun Yu-ila (1760-1795) i jego 7 Towarzyszy i 1 października również otrzymała nihil obstat Kongregacji Spraw Kanonizacyjnych (Prot. N. 2119-1/96) ${ }^{11}$.

\footnotetext{
${ }^{7}$ Sacra Congregatio pro Causis Sanctorum, Normae servandae in inquisitionibus ab Episcopis faciendis in causis sanctorum (7.02.1983), AAS 75 (1983) 396-403; tt. na j. polski H. Misztal, w: H. MiszTal, L. Fiejdasz-BuczeK, Postepowanie kanonizacyjne $w$ diecezji lub eparchii, Lublin: Wydawnictwo KUL 2017, s. 259-269.

${ }^{8}$ History of the cause, [w:] Positio, s. 11

${ }^{9}$ General introduction. Brief profile of the servants of God, [w:] Positio, s. 12.

${ }^{10}$ General introduction. History of the cause, [w:] Positio, s. 13-14.

${ }^{11}$ Paulus Yun Yuil (Yangkun c. 1760 - Suvon 28 iun. 1795) et VII Socii, viri laici, in odium fidei, uti fertur, interfecti ( $†$ 1795-1801), CONGREGATIO DE CAUSIS SANCTORUM, Index ac status causarum, Città del Vaticano: Libreria Editrice Vaticana 1999, s. 335.
} 
Mając na uwadze te i inne starania, jesienią 1997 r. podczas Zgromadzenia Generalnego Konferencja Episkopatu Korei postanowiła połączyć wszystkie inicjatywy zmierzające do wyniesienia na ołtarze pierwszych i kolejnych świadków wiary pod nazwą „Wspólne promowanie beatyfikacji i kanonizacji męczenników koreańskich", prezentując siebie jako powoda sprawy w Kongregacji Spraw Kanonizacyjnych ${ }^{12}$.

Po konsultacjach z Kongregacją ówczesny prefekt kard. J.S. Martins w oficjalnym liście doradził konferencji episkopatu, by poprosiła o dyspensę od normy 5a Normae servandae. Ta nadeszła 4 sierpnia 2002 r. i do sprawy Pawła Yun Yu-ila (1760-1795) i jego 7 Towarzyszy oraz Pawła Yun Ji-chunga (1759-1791) i 4 Towarzyszy dołączono 111 nowych kandydatów na ołtarze ${ }^{13}$.

\section{FORUM KOMPETENTNE}

„Prawo prowadzenia dochodzeń o życiu [...] męczeństwie i opinii [...] męczeństwa [...] przysługuje biskupom diecezjalnym albo innym hierarchom $\mathrm{z}$ nimi zrównanym $\mathrm{w}$ prawach, $\mathrm{w}$ zakresie ich jurysdykcji, czy to $\mathrm{z}$ urzędu, czy na prośbę poszczególnych wiernych lub prawnych stowarzyszeń i ich pełnomocników"14. Zgodnie z normą 5a Normae servandae w prowadzeniu spraw kanonizacyjnych właściwy jest ten biskup diecezjalny lub eparchialny, na którego terytorium kandydat na ołtarze zmarł, „chyba że okoliczności szczególne zaaprobowane przez Kongregację wskazywałyby co innego". $\mathrm{W}$ prezentowanej sprawie, $\mathrm{z}$ racji miejsca śmierci, kompetentnych było 11 biskupów diecezjalnych ${ }^{15}$. Zgodnie jurysprudencją Kongregacji utrwaloną w kan. $2001 \S 1$ nieobowiązującego dziś Kodeksu Prawa Kanonicznego z 1917 r. ${ }^{16}$, a obecnie wyrażoną expressis verbis w art. 32 instrukcji Sanctorum Mater, dochodzenie w odniesieniu do większej liczby męczenników

${ }^{12}$ General introduction. History of the cause, [w:] Positio, s. 13.

${ }^{13}$ Tak instrukcja Kongregacji (Prot. N. Var. 520/00 z 19 grudnia 2000 r.), [w:] Positio, s. 14-15.

${ }^{14}$ IoAnnes Paulus II, Constitutio apostolica Divinus perfecionis Magister. Modus procedenti in Causarum canonizationis instructione recognoscitur et Sacrae Congregationis pro Causis Sanctorum nova datur ordinatio (25.01.1983), AAS 75(1983) 349-355.

${ }^{15}$ Męczennicy ponieśli śmierć na terenie diecezji: Seul (38), Jeonju (24), Daegu (19), Daejeon (13), Suwon (11), Pusan (5), Cheongju (5), Masan (4), Wonju (3), Andong (1) oraz Chunchon (1). The CATHOlic Bishops' CONFEREnCE OF Korea, Dioceses where the Servants of God "Paul Yun Ji-chung and 123 Companions" were martyred and their numbers, [w:] Positio, [npg].

${ }^{16}$ Codex Iuris Canonici Pii X Pontificis Maximi iussu digestus Benedicti Papae XV auctoritate promulgatus, fontium annotatione et indice analytico-alphabetico ab emo Petro Gasparri auctus, Romae: Typis Polyglottis Vaticanis 1930, s. 471. 
można prowadzić, jeśli słudzy Boży zostali zabici podczas tego samego prześladowania (tzn. w tych samych okolicznościach) i jeśli zginęli w tym samym miejscu, tzn. w Korei ${ }^{17}$. Kompetencję do prowadzenia sprawy powierzono biskupowi Masan ${ }^{18}$. Jako głównego męczennika wybrano Pawła Yun Ji-chunga (1759-1791) ${ }^{19}$. Diecezjalny proces beatyfikacyjny rozpoczął się 5 lipca 2004 r. Od 23 lipca 2004 do 20 stycznia 2006 r. trybunał odbył 16 sesji przesłuchań świadków. Następnie przetłumaczono akta na język angielski i 20 maja 2009 r. definitywnie zamknięto fazę diecezjalną procesu ${ }^{20}$.

\section{CENZURA TEOLOGICZNA PISM DRUKOWANYCH}

W prawie kanonizacyjnym zasadą jest, że zanim biskup kompetentny rozpocznie proces, podda ocenie teologicznej opublikowane pisma kandydata na ołtarze, upewniając się, czy nie znajduje się w nich nic, co sprzeciwia się wierze lub dobrym obyczajom ${ }^{21}$. W gronie 124 Męczenników koreańskich znajdował się Jeong Yak-jong (1760-1801), po chrzcie Augustyn (1786) - arystokrata i katecheta, w tamtym czasie jeden z najwybitniejszych ludzi Kościoła katolickiego Korei, autor pierwszego katechizmu katolickiego dla Koreańczyków Jugyo-Yoji ${ }^{22}$ i instrukcji dla katechumenów. Cechowała go głęboka wiedza filozoficzna i religijna. Miał dar przekonywania innych oraz silne cechy przywódcze. Aresztowano go 11 lutego 1801 r. podczas jednego z najtragiczniejszych prześladowań Shinyu (1801-1802) ${ }^{23}$. Jego dwutomowy katechizm szybko zyskał popularność. Napisany w koreańskim piśmie hangul i poparty licznymi przykładami zaczerpniętymi z kultury koreańskiej, był - jak ocenił czytający go wówczas Aleksander Hwang Sa-yeon (1775$1801)^{24}$ - tak łatwy, ,że nawet niewykształcona kobieta i dziecko mogły go

${ }^{17}$ General introduction. History of the cause, [w:] Positio, s. 14-15.

${ }^{18}$ Presentazione di p. Zdzisław Józef Kijas OFMConv. Relatore della Causa, [w:] Positio, s. V; History of the cause, [w:] tamże, s. 14-15.

${ }^{19}$ H. Misztal, L. Fiejdasz-BuczeK, Postępowanie kanonizacyjne, s. 83-85.

${ }^{20}$ General introduction. History of the cause, [w:] Positio, s. 16-18.

${ }^{21} \mathrm{Nr} 2,2^{0} \mathrm{DpM}, \mathrm{nr} 13 \mathrm{NS}$.

${ }^{22}$ Lub jak podaje Donald Baker: „Chugyo joji”. D. BAKER, The Korean Catholic Church's first hundred years: guest editor's introduction, „Acta Koreana” 15 (2012), nr 1, s. 12.

${ }^{23}$ Life and martyrdom of the servants of God, [w:] Positio, s. 101-103.

${ }^{24}$ Szerzej: Alexander Y. Hwang, Lidia T. KIM, The Silk Letter of Alexander Sayông Hwang Introduction and Abridged Translation, "Missiology: An International Review" 37(2009), nr 2, s. $165-179$. 
zrozumieć” ${ }^{25}$. Katechizm był niezwykle cenny dla Koreańczyków i doprowadził rzesze ludzi do Kościoła katolickiego.

Pierwszy z cenzorów teologów wyraził przekonanie, że z punktu widzenia teologii dogmatycznej katechizm zawierał ważną substancję teologiczną, zaś z punktu widzenia historii Kościoła wyjaśniał jego doktrynę w pytaniach i odpowiedziach. Odegrał znaczącą rolę w katechizowaniu osób, które przygotowywały się do chrztu, i neokatechumenów, a także w ewangelizowaniu Korei $^{26}$. Drugi cenzor po omówieniu struktury katechizmu (tom I składał się z 32 sekcji, tom II - z 11 sekcji) ocenił, że był to najlepiej w historii Kościoła katolickiego w Korei inkulturowany katechizm ${ }^{27}$.

\section{CHARAKTERYSTYKA 124 ŚWIADKÓW WIARY}

Prezentowani Męczennicy pochodzą z terenu dzisiejszych 11 diecezji ${ }^{28}$. Pośród nich są protomęczennicy Kościoła katolickiego w Korei: Paweł Yun Ji-chung (1759-1791) i Jakub Kwon Sang-yeon (1751-1791) zamordowani 8 grudnia 1791 r. W tej grupie znajduje się 123 świeckich Koreańczyków i tylko 1 kapłan o. Jakub Zhou Wen-mo (1752-1801), misjonarz z Chin, który do Korei przybył 23 grudnia $1794 \mathrm{r}^{29} \mathrm{~W}$ czasie jego działalności misyjnej liczba wiernych wzrosła z 4000 do $10000^{30}$. Zorganizował wspólnotę kościelną i formował przywódców świeckich. Działał na rzecz wolności religijnej. Zabiegał u biskupa Pekinu, by wysłał misjonarzy do Korei na zachodnioeuropejskich statkach. Jemu raportował swoją pracę misyjną w latach 1796-1800. Zapamiętano go jako doskonałego misjonarza, będącego wzorem dla kolejnych pokoleń koreańskich księży ${ }^{31}$.

${ }^{25}$ Vote of Theological Censors, [w:] Positio, s. 592.

${ }^{26}$ Tamże, s. 591-592.

${ }^{27}$ Tamże, s. 593-594; Z.J. KIJAs, The essentials elements of the Lord's Teaching. The Manual to transmit the Faith in Korea, „Studia Missionalia” 62(2013), s. 183-198.

${ }^{28}$ Mianowicie z: Seulu (38), Jeonju (24), Daegu (19), Daejeonu (13), Suwonu (11), Pusan (5), Cheongju (5), Masan (4), Wonju (3), Andong (1) oraz Chunchon (1). The Catholic Bishops' Conference of Korea, Dioceses where the Servants of God "Paul Yun Ji-chung and 123 Companions" were martyred and their numbers, [w:] Positio, [npg].

${ }^{29}$ Pracę duszpasterską rozpoczął w Wielkanoc 1795 r. Z powodu jego działalności misyjnej wybuchło prześladowanie Shinyu (1801-1802), podczas którego wielu katolików straciło życie, ale go nie wydało. 24 kwietnia 1801 r. sam oddał się władzom, wkrótce został ścięty mieczem w Saenamteo w pobliżu rzeki Han.

${ }^{30}$ The Lives of 124 Blessed Martyrs of Korea. James Zhou Wen-mo (1752-1801), “CBCK. Newsletter" 22(2015), nr 1, s. 8.

${ }^{31}$ Life and martyrdom of the servants of God, [w:] Positio, s. 98-99. 
W charakteryzowanej liczbie Świadków Wiary aż 24 to męczennice. Najmłodsza Anastazja Yi Bong-geum (1827-1839), dziewczynka z plebsu, w chwili śmierci miała niespełna 12 lat. Aresztowana w Gwangju w 1839 r. i przewieziona do Jeonju nie dała się zwieść głównemu oficerowi i strażnikom, którzy mówili jej: ratuj się, bo jesteś „małą, słodką dziewczynką”. Wytrwała w heroicznej decyzji do końca, mimo tego, iż była świadkiem męczeństwa swojej matki Barbary Kim Jo-i (†1839). Została powieszona w więzieniu w Jeonju 5 lub 6 grudnia 1939 r. Taką samą śmierć poniosła najstarsza spośród kobiet, 56-letnia Brygida Choe (1783-1839) ${ }^{32}$. Osiemnastoletnią Barbarę Sim A-gi (1783-1801) zakatowano w więzieniu ${ }^{33}$. Lat 25 miała Vivian Mun Yeong-in (1776-1801), gdy została ścięta przy Małej Zachodniej Bramie w Seulu ${ }^{34}$. W ten sam sposób śmierć poniosła 20-letnia Lutgarda Yi Sun-i (1782-1802) ) $^{35}$ i 36-letnia Teresa Kwon Cheon-rye (1783-1819) ${ }^{36}$. Wiek 6 męczennic nie jest znany. Spośród setki mężczyzn najmłodszy był 17-letni Jan Yu Mun-seok (1784-1801) oraz 19-letni Jakub Oh Jong-rye (1821-1840). Najstarszy z męczenników, pochodzący z rodziny arystokratycznej Pius Kim Jin-hu (1739-1814), miał 75 lat.

Męczennicy pochodzili ze wszystkich warstw społecznych: z arystokracji, klasy średniej, plebsu. Ze względu na stan wśród zamęczonych jest: kapłan, 3 pary małżeńskie, osoby zamężne, dziewice, wdowy, nieżonaci oraz dziecko. Ze względu na wykonywany zawód i rolę w społeczeństwie najwięcej zidentyfikowano przywódców świeckich (liderów) - przynajmniej 17; 14 laików, 10 katechetów, 6 farmaceutów, 4 niższych urzędników, 4 nauczycieli, 3 łączników; po 2 tajnych wysłanników, uczonych i kupców. Byli także: lekarz, tłumacz, garncarz, rolnik, handlarz, dama dworu, służący i oficer wojskowy oraz inni, których zawody nie zostały określone.

Szczególne znaczenie dla wiernych w rodzącym się Kościele miał przykład dwóch par małżeńskich: Jana Yu Jung-cheola (1779-1801) i Lutgardy Yi Sun-i (1782-1802) $)^{37}$ oraz Piotra Jo Suk (1787-1819) i Teresy Kwon Cheon-rye (17841819). Chociaż zawarli małżeństwo według zasad konfucjańskich, zrealizowali pragnienie życia w białym małżeństwie zgodnie z zaleceniami Ewangelii.

${ }^{32}$ Tamże, s. 213-216.

33 Tamże, s. 118-119.

${ }^{34}$ Servant of God Vivian Mun Yeong-in (1776-1801), Nr 35, [w:] Positio, s. 124.

${ }^{35}$ Servant of God Lutgarda Yi Sun-i (1782-1802), Nr 66, [w:] Positio, s. 164; szerzej: D.J. TORREY, Transcendence and anxiety in the prison letters of catholic martyr Yi Suni Ludgarda (1779-1802), „Religion \& Literature” 47(2016) 3, s. 27-55.

${ }^{36}$ Life and martyrdom of the servants of God, [w:] Positio, s. 191.

${ }^{37}$ D.J. TORREY, Transcendence and anxiety, s. 25-55. 
W gronie beatyfikowanych są krewni oraz członkowie ich rodzin kanonizowani przez Jana Pawła II w 1984 r. w Seulu. Syn Piusa Kima Jin-hunga (1739-1814) - Andrzej Kim Jong-han (?-1816) znajduje się w gronie 124 męczenników. Jego syn (a wnuk Piusa Kima) Ignacy Kim Jae-jun (Che-jun) (1796-1839) - był kanonizowany w grupie 103 męczenników 6 maja 1984 r., którym przewodził ks. Andrzej Kim (1821-1846), pierwszy kapłan pochodzenia koreańskiego, wnuk Ignacego Kima i prawnuk Piusa Kima ${ }^{38}$.

\section{PRZEŚLADOWCA I SPOSOBY ZADAWANIA ŚMIERCI}

Według nauki papieża Benedykta XIV (1740-1758), prześladowca jest osobą różną od męczennika ${ }^{39}$. Zadaje śmierć z nienawiści do wiary lub cnoty z wiary wypływającej. Może być osobą fizyczną lub prawną, działa samodzielnie lub przez kogoś. Prawo wyróżnia prześladowcę indywidualnego, zbiorowego (np. system totalitarny) i w szerszym słowa znaczeniu (np. aparat administracyjny, ustawodawstwo rewolucyjne, organy władzy sądowniczej) ${ }^{40}$.

Kościół katolicki w Korei rozwinął się w schyłkowym okresie panowania dynastii Yi (potocznie zwanej Choson, Joseon), która rządziła w latach 1392-1910. Dominujący w państwie konfucjanizm miał olbrzymi wpływ na organizację porządku społecznego w całej Azji. Szczególnie w Korei społeczeństwo było zorganizowane na wzorcach konfucjańskich ${ }^{41}$. Tutaj konfucjanizm występował w skrajnie ortodoksyjnej formie, zwanej również neokonfucjanizmem. Zakładał ścisłą hierarchię społecznych relacji: syna do ojca, młodszego brata do starszego, żony do męża, poddanego do króla ${ }^{42}$. W społeczeństwie kastowym na czele hierarchii społecznej stali arystokraci zwani Yangbanami, zwykli obywatele yangin nie umieli pisać i czytać. Byli

${ }^{38}$ Life and martyrdom of the servants of God, [w:] Positio, s. 170; 186.

${ }^{39}$ Congregatio De CAusis SAnctorum, Benedictus XIV (Prosper de Lambertinis), De Servorum Dei Beatificatione et Beatorum Canonizatione III/1, Cittá del Vaticano: Libreria Editrice Vaticana; Congregazione delle Cause DeI Santi, Benedetto XIV (Prospero Lambertini), La beatificazione dei Servi di Dio e la Canonizzazione dei Beati III/1, Cittá del Vaticano: Libreria Editrice Vaticana 2015, s. 262-370; 409-489.

${ }^{40}$ H. MiszTal, Prawo kanonizacyjne. Instytucje prawa materialnego, zarys historii, procedura, Lublin: Wydawnictwo Diecezjalne w Sandomierzu 2003, s. 61-66.

${ }^{41}$ G. Rozman, Can Confucianism Survive In An Age Of Universalism And Globalization?, "Pacific Affairs" 75 (2002), nr 1, s. 17-18.

${ }^{42}$ F.J. LuHMANN, $A$ study of the relationship between filial piety and age of urban residents in Korea and their attitude toward old people in general, DSW 1984, s. 17. 
pozbawieni praw politycznych. Przedstawiciele klasy średniej, rzemieślnicy, lekarze i przedstawiciele innych zawodów zwani chungin dzielili się na 9 grup ${ }^{43}$.

Jedną z centralnych zasad konfucjanizmu była zasada Xiao - nabożności synowskiej, spisana w Hyokyeong ${ }^{44}$. Reguła Xiao nie była tylko zwykłym przykazaniem moralnym, ale cnotą kardynalną, fundamentem porządku rodzinnego. Przestrzeganie Xiao gwarantowało stabilność państwa i społeczeństwa $^{45}$. Z zasadą nabożności synowskiej wiązał się ściśle kult przodków. Na drewnianej, czerwonej deseczce zapisywano imię zmarłego i wierzono, że na niej mieszka jego dusza. Następnie tabliczkę umieszczano w domowym ołtarzyku, według ściśle określonej za życia hierarchii, i w ustalone dni roku składano ofiary, prosząc także o pomoc lub radę ${ }^{46}$. Ten kult przodków uważany za głęboki wyraz synowskiej pobożności, był świętym obowiązkiem każdego z dynastii Joseon, a jego naruszenie uważane było za niewybaczalną zbrodnię ${ }^{47}$.

W 1790 r. Paweł Yun Yu-il (1760-1795) przywiózł od bpa Aleksandra de Guvea z Pekinu oficjalne stanowisko Kościoła katolickiego zakazujące odprawiania rytów ku czci przodków ${ }^{48}$. Prześladowanie Kościoła rozpoczęło się w 1791 r., kiedy Paweł Yun Ji-chung (1759-1791) i Jakub Kwon Sangyeon (1751-1791) odmówili wykonania rytuałów związanych z kultem przodków oraz spalili tabliczki z ich imionami ${ }^{49}$. Ponadto Paweł nie dopełnił obowiązków pogrzebowych swojej matki. Zostali skazani na śmierć, a ich rody zdegradowano. Prześladowanie Sinhae (1791-1793) było pierwszym z serii 11 fal prześladowań, które trwały do $1888 \mathrm{r} .{ }^{50}$ Zgodnie wskazuje się,

${ }^{43}$ A. FINCH, The Pursuit of Martyrdom in the Catholic Church in Korea before 1866, "Journal of Ecclesiastical History" 60 (2009), nr 1, s. 96.

${ }^{44}$ A. Egiguren Iraola, True Confucians, bold Christians Korean missionary experience. A model for the third millennium, Amsterdam: Rodopi 2007, s. 208.

${ }^{45}$ A. Kość, Chrześcijaństwo a kultura koreańska, „Studia Nauk Teologicznych” 5 (2010), s. 141.

${ }^{46}$ Szerzej: E. KAJDAŃSKI, Chiny. Leksykon, Warszawa: Spółdzielnia Wydawniczo-Handlowa „Książka i Wiedza” 2011, s. 311-312; W. Eberhard, Symbole chińskie. Słownik, Kraków: Towarzystwo Autorów i Wydawców Prac Naukowych „Universitas” 2007, s. 255-256.

${ }^{47}$ Brief history of ,,Joseon” Dynasty in Korea, [w:] Positio, s. 34; Ch. DAllet, Histoire de l'Église de Corée: précédée d'une introduction sur l'histoire, les institutions, la langue, les moeurs et coutumes coréennes avec carte et planches par Ch. Dallet Missionnaire apostolique, Société des Missions-Etrangères, Paris 1874, tome premier, s. 33-35.

${ }^{48}$ Brief history of Catholic Church of Catholic Church in Korea, [w:] Positio, s. 40; H. OGAREK-CHOI, Tonghak. Nauka Wschodu, Warszawa: Iskry 1984, s. 15.

${ }^{49}$ Catholics In Korea Activity Workbook, The History Of The Catholic Church In Korea, OptionC 2014, s. 2.

${ }^{50}$ Prześladowania i liczba męczenników: Sinhae (1791-1793) - 3, Eulmyo (1795) - 3, Jeongsa (1797-1800) - 8, Shinyu (1801-1802) - 53, 1814 r. - 1; Eulhae (1815-1816) - 12, 1819 r. - 2; Jeonhae (1827-1835) - 4, Gihae (1839-1840) - 18, Byeongo (1846) - 0, Gyeongsin (1860) - 0, 
że prześladowcą była dynastia Joseon i jej przedstawiciele jako osoby bezpośrednio lub pośrednio zadające śmierć ${ }^{51}$.

W omawianym gronie 124 męczenników - 106 prześladowca zadał śmierć w sposób bezpośredni: przez ścięcie mieczem zginęło 78 osób, przez powieszenie - 11 , zakatowanie -10 , prawdopodobnie powieszenie -3 , poćwiartowanie -2 , stracenie -1 i uduszenie -1 . Śmierć pośrednią - ex aerumnis carceris - poniosło 18 męczenników na skutek: wyczerpania udręczonego torturami organizmu, wycieńczenia, zagłodzenia, nieprzeżycia tortur, choroby i tortur.

\section{BEATYFIKACJA}

Beatyfikacji Męczenników dokonał osobiście papież Franciszek. Wprowadzona przez papieża Benedykta XVI 14 maja 2005 r. ${ }^{52}$ praktyka delegowania na ceremonię beatyfikacyjną przedstawiciela Ojca Świętego, doczekała się regulacji w wydanym 29 września 2005 r. - na polecenie papieża Benedykta XVI - komunikacie w sprawie zmian w obrzędach beatyfikacji ${ }^{53}$. Motywem tej decyzji, konsultowanej z Sekretariatem Stanu, było mocniejsze podkreślenie istotnej różnicy między beatyfikacją a kanonizacją oraz wyraźne włączenie Kościołów partykularnych w sam akt beatyfikacji. Wyjątkiem natomiast nie jest miejsce uroczystości - Seul. Komunikat, jako miejsce najwłaściwsze ze względów duszpasterskich, wskazuje na diecezję, która wniosła sprawę nowego błogosławionego, albo na inne, bardziej odpowiednie $\mathrm{w}$ tej samej prowincji kościelnej czy regionie. Zawsze jednak podkreśla się, że każda beatyfikacja jest aktem papieskim. Wyraża to list apostolski podpisany przez papieża, w którym Jego Świątobliwość, na mocy swej apostolskiej władzy, zezwala na beatyfikację oraz na coroczne obchodzenie ich świąt „w miejscach i według reguł przewidzianych przez prawo”. Zgodnie z najnowszą praktyką, obrzęd beatyfikacji odbywa się podczas liturgii

Byeongin (1866-1868) - 19, 1888 r. - 1. Szerzej: Chronological table of persecutions in Korea, [w:] Informatio. Positio, s. 45-51.

${ }^{51}$ Presentazione di p. Zdzisław Józef Kijas OFMConv. Relatore della Causa, [w:] Positio, s. V. (V-XI); History of the cause, [w:] tamże, s. 14-15.

52 J.S. MarTins, Otworzyty serca Duchowi Świętemu. 14 V 2005 - Homilia prefekta Kongregacji Spraw Kanonizacyjnych podczas Mszy św. Beatyfikacyjnej, „L'Osservatore Romano” [wyd. pol.] 26 (2005), nr 7-8 (275), s. 6-7 [dalej: LR].

${ }^{53}$ J.S. MARTINS, Nowe procedury obrzędu beatyfikacji, LR 27 (2006), nr 3 (281), s. 42-44; CCS, Attentis conclusionibus, 29.09.2005, „Communicationes” 39 (2007), s. 56. 
eucharystycznej, po akcie pokuty i przed śpiewem Gloria ${ }^{54}$. Tę praktykę podtrzymano w tym przypadku. Po akcie pokuty bp Franciszek Ksawery Ahn Myong-ok, przewodniczący Specjalnej Komisji do Spraw Beatyfikacji i Kanonizacji, powołanej przez Konferencję Episkopatu Korei, poprosił Ojca Świętego o zaliczenie Pawła Yun Ji-chunga i 123 Towarzyszy do grona błogosławionych. Po odczytaniu przez postulatora biografii Męczenników Ojciec Święty wypowiedział po łacinie formułę beatyfikacyjną i ogłosił, że ich wspomnienie liturgiczne będzie obchodzone 31 maja. Następnie odsłonięto obraz 124 Męczenników, a bp Francis Xavier Ahn Myong-ok wyraził Ojcu Świętemu wdzięczność za beatyfikację i wraz z postulatorem sprawy wymienili z papieżem Franciszkiem uścisk pokoju. Po tych czynnościach odśpiewano hymn „Chwała na wysokości Bogu”.

W homilii papież Franciszek nawiązał do początków Kościoła katolickiego w Korei: „Tajemniczym zrządzeniem Bożej opatrzności wiara chrześcijańska nie dotarła do wybrzeży Korei za pośrednictwem misjonarzy. Wniknęła poprzez serca i umysły samych Koreańczyków. Pobudką do niej była ciekawość intelektualna, poszukiwanie prawdy religijnej”55. To poznanie „nauki o Jezusie wkrótce doprowadziło do spotkania z samym Panem, do pierwszych chrztów, do pragnienia pełnego życia sakramentalnego i kościelnego oraz do początków zaangażowania misyjnego. Zaowocowało ono także we wspólnotach, które czerpały inspirację z Kościoła pierwszych wieków, w którym wierni mieli naprawdę jedno serce i jednego ducha, niezależnie od tradycyjnych różnic społecznych, i wszystko mieli wspólne (por. Dz 4, 32)"56.

Franciszek zauważył, że: „Zwycięstwo męczenników, ich świadectwo o potędze Bożej miłości dziś nadal przynosi owoce w Korei, w Kościele, który wzrasta dzięki ich ofierze" ${ }^{97}$. Istotnie, według pewnych danych, Kościół

${ }^{54}$ J.S. MARTINS, Nowe procedury obrzędu beatyfikacji, s. 43; szerzej o reformie obrzędu beatyfikacji i jego historycznych uwarunkowaniach zob. L. FIEJDASZ-BuCZEK, Sprawy kanonizacyjne za pontyfikatu papieża Benedykta XVI. Studium prawno-kanoniczne, Lublin: Wydawnictwo KUL 2019, s. 56-74.

${ }^{55}$ Franciscus, Homilia. Occasione Beatificationis CXXIV Martyrum Coreanorum apud Portam vulgo Gwanghwamun Seuli (16.08.2014), AAS 106 (2014) 683; tekst w j. pol.: FRANCISZEK, Dziedzictwo męczenników. 16 VIII 2014 - Msza św. w Seulu i beatyfikacja Pawła Yuna Ji-chunga i jego 123 towarzyszy, LR 35 (2014), nr 8-9 (365), s. 14.

${ }^{56}$ Franciscus, Homilia. Occasione Beatificationis CXXIV Martyrum Coreanorum, s. 683-684; tekst w j. pol.: FrANCISZEK, Dziedzictwo męczenników, s. 14.

${ }^{57}$ FrancISCus, Homilia. Occasione Beatificationis CXXIV Martyrum Coreanorum, s. 683-685; tekst w j. pol.: FranciszeK, Dziedzictwo męczenników, s. 13-14. Do tego faktu nawiązał także w przemówieniu do biskupów koreańskich, zob. Franciscus, Allocutio. Ad Episcopos Coreanos apud Sedem Coetus Episcoporum Coreanorum, (14.08.2014), AAS 106 (2014), s. 695-696; 
katolicki w Korei Południowej jest najszybciej wzrastającym Kościołem na świecie ${ }^{58}$, jego instytucje cieszą się największym zaufaniem w społeczeństwie $^{59}$, a Korea jest prawdopodobnie jedynym państwem na świecie, gdzie liczba katolików rośnie wraz z rozwojem gospodarczym. Tomas Han Honsoon, ambasador Republiki Korei przy Stolicy Apostolskiej (2010-2013), w wywiadzie udzielonym „Asia News” z racji 50. rocznicy nawiązania stosunków dyplomatycznych ze Stolicą Apostolską, powołując się na poważne obliczenia, prognozuje, że w 2044 r. katolicy w Korei stanowić mogą nawet $56 \%$ społeczeństwa ${ }^{60}$. „Z kraju misyjnego Korea stała się dziś krajem misjonarzy", a Kościół powszechny nieustannie korzysta z wielu kapłanów i zakonników, wysłanych z tego kraju w świat ${ }^{61}$.

\section{PRZESŁANIE BEATYFIKACJI}

Beatyfikacja Pawła Yun Ji-chunga i jego 123 Towarzyszy zachęca katolików koreańskich, by „pamiętali o wielkich rzeczach, jakich Bóg dokonał w tym kraju, i strzegli niczym skarbu dziedzictwa wiary i miłości”, powierzonego im przez przodków ${ }^{62}$.

Franciszek zwrócił uwagę na znaczenie, godność, piękno powołania i rolę świeckich w Kościele katolickim w Korei ${ }^{63}$, który „,jest spadkobiercą wiary

FRANCISZEK, Bądźcie stróżami pamięci i nadziei. 14 VIII 2014 - Spotkanie z biskupami koreańskimi w Seulu, LR 35 (2014), nr 8-9 (365), s. 6.

${ }^{58}$ S. MAGISTER, Corea del Sud, la tigre asiatica della Chiesa, http://chiesa.espresso.repubblica.it/ articolo/1350223.html [dostęp: 16.03.2018]. Szczegółowe statystyki z lat 1997-2016 dostępne są na stronie Konferencji Episkopatu Korei pod linkiem: http://english.cbck.or.kr/statistics [dostęp: 16.03.2018].

${ }^{59}$ Corea, la Chiesa cattolica è la religione più stimata del Paese, http://www.asianews.it/notizie-it/ Corea,-la-Chiesa-cattolica-\%C3\%A8-la-religione-pi\%C3\%B9-stimata-del-Paese-35726.html [dostęp: 16.03.2018].

${ }^{60}$ T. Han Hong-Soon, Corea del Sud - Vaticano. Ambasciatore Han: I 50 anni dei rapporti fra Corea e Santa Sede, l'evangelizzazione e il bene comune, http://www.asianews.it/notizie-it/ Ambasciatore-Han:-I-50-anni-dei-rapporti-fra-Corea-e-Santa-Sede,-1\%E2\%80\%99evangelizzazione -e-il-bene-comune-29857.html [dostęp: 14.02.2018].

${ }^{61}$ Franciscus, Allocutio. Ad Episcopos Coreanos, s. 696; FranciszeK, Bądźcie stróżami pamięci i nadziei, s. 6 .

${ }^{62}$ Franciscus, Homilia. Occasione Beatificationis, s. 683; FrANCISZEK, Dziedzictwo męczenników, s. 14; Franciscus, Homilia. Ad Ductores Apostolatus apud Stadium vulgo World Cup Stadium in Coreana urbe Daejeon Eucharistiam celebrat (15.08.2014), AAS 106 (2014) 682; Franciszek, Patrzymy na Maryje jako na Matke naszej nadziei. 15 VIII 2014 - Msza św. na Stadionie Pucharu Świata w Tedzonie, LR 35 (2014), nr 8-9 (365), s. 9.

${ }^{63}$ Franciscus, Homilia. Occasione Beatificationis, s. 684; FrANCISZEK, Dziedzictwo męczenników, s. 14. 
pokoleń ludzi świeckich" ${ }^{64}$. Rodziny chrześcijańskie, które codziennym przykładem wychowują młodych w wierze, przyczyniają się do wzrostu wiary, stają się „,zaczynem świętości i prawdy: solą ziemi i światłem świata”, i w tym mogą brać przykład z męczenników ${ }^{65}$. Męczennicy uczą odwagi. Są bezkompromisowym przykładem wielkiego poświęcenia, zaparcia się siebie, pójścia za Chrystusem aż do przelania krwi. Uczą „ogołocenia się ze wszystkiego, co mogło ich oddalać od Chrystusa - majątków i ziemi, prestiżu i honoru"66. Uczą życia w pełni dla Boga i bliźniego ${ }^{67}$.

Wzór męczenników poucza o znaczeniu miłości w życiu wiary. „Czystość ich świadectwa o Chrystusie, wyrażającego się w uznaniu równej godności wszystkich ochrzczonych, doprowadziła ich do braterskiego życia, co stanowiło wyzwanie dla sztywnych struktur społecznych ich epoki. Niezgoda na rozdzielenie podwójnego przykazania miłości Boga i miłości bliźniego zaowocowała wielkim zatroszczeniem się o potrzeby braci”. Dlatego przykład Pawła Yun Ji-chuna i jego 123 Towarzyszy uczy miłości i solidarności ${ }^{68}$, służby bliźniemu, troski o ubogich i tych z niższych warstw społecznych. Troska ta powinna przejawiać się w konkretnych dziełach miłosierdzia oraz nieustannym dziele promocji społecznej, zawodowej i edukacyjnej ${ }^{69}$.

Dziedzictwo Męczenników niesie przesłanie pokoju. Ich przykład może inspirować „do harmonijnej pracy na rzecz bardziej sprawiedliwego, wolnego i pojednanego społeczeństwa, przyczyniając się w ten sposób do pokoju i ochrony wartości autentycznie ludzkich w tym kraju i na całym świecie"70. To przesłanie ma szczególne znaczenie dla dotkniętego podziałami i konfliktami Półwyspu Koreańskiego, podzielonego od ponad sześćdziesięciu lat ${ }^{71}$.

${ }^{64}$ Franciscus, Allocutio. Ad Ductores Apostolatus Laici apud Centrum Spiritualitatis in loco vulgo Kkottongnae (16.08.2014), AAS 106 (2014) 711; FRANCISZEK, Godność zarabiania na chleb powszedni. 16 VIII 2014 - Spotkanie z liderami apostolstwa świeckich w Kkottongnae, LR 35 (2014), nr 8-9 (365), s. 17.

${ }^{65}$ Franciscus, Homilia. Occasione Beatificationis, s. 684; FrANCISZEK, Dziedzictwo męczenników, s. 14.

66 Tamże.

${ }^{67}$ Franciscus, Allocutio. Ad Publicas Auctoritates Coreae Meridionalis apud Aedes Praesidiales (14.08.2014), AAS 106 (2014) 692-693; FRANCISZEK, W krainie spokojnego poranka. 14 VIII 2014 - Spotkanie z przedstawicielami rządu i wtadz państwowych $w$ pałacu prezydenckim w Seulu, LR 35 (2014), nr 8-9 (365), s. 4.

${ }^{68}$ Franciscus, Allocutio. Ad Ductores, s. 711; FranciszeK, Godność zarabiania, s. 17.

${ }^{69}$ Franciscus, Allocutio. Ad Episcopos Coreanos, s. 697-698; FrANCISZEK, Badźcie stróżami, s. 7.

${ }^{70}$ Franciscus, Homilia. Occasione Beatificationis, s. 684; FrancISZEK, Dziedzictwo męczenników, s. 14.

${ }^{71}$ Franciscus, Homilia. Apud Cathedralem ecclesiam vici Myeongong Seuli Eucharistiam pro pace et concordiae reconciliatione in Corea celebratio (18.08.2014), AAS 106 (2014) 690; 


\section{ZAKOŃCZENIE}

Zainteresowanie Kościołem katolickim w Korei ożyło ponownie wraz z podróżą apostolską papieża Franciszka na kontynent azjatycki w sierpniu 2014 r. Trzecia podróż zagraniczna Franciszka i trzecia papieża do „kraju spokojnego poranka", tym razem połączona była z beatyfikacją Pawła Yun Ji-chunga i jego 123 Towarzyszy Męczenników oraz z celebrowaniem VI Azjatyckich Dni Młodzieży. Przygotowania do rozpoczęcia procesu beatyfikacyjnego Męczenników trwały ponad 20 lat, a sam proces w fazie diecezjalnej i rzymskiej pochłonął kolejne 12 lat. Ten, zdawałoby się długi, czas oczekiwania na wpisanie Ojców założycieli Kościoła katolickiego w Korei do kalendarza błogosławionych, zaowocował dobrym przygotowaniem skomplikowanego procesu grupy męczenników, wypełnieniem wszystkiego, czego wymaga prawo kanonizacyjne, oraz duchowym przygotowaniem wiernych do tego wydarzenia. Nie odnotowano jednak, jak to miało miejsce w tym samych czasie po podróży apostolskiej Jana Pawła II, tzw. efektu Franciszka, o czym poinformowało Radio Watykańskie 19 września 2016 r. Przesłaniu ubóstwa i ogołoceniu się ze wszystkiego na wzór męczenników sprzeciwiają się pewne grupy katolickie, oceniając je ,jako nacechowane politycznie i promujące komunizm". Ten stan rzeczy motywuje Specjalną Komisję Konferencji Episkopatu Korei do Spraw Beatyfikacji i Kanonizacji Męczenników, która 22 lutego 2017 r. ogłosiła rozpoczęcie procesu beatyfikacyjnego sługi Bożego Jana Chrzciciela Yi Byeoka, zwanego Piotrem Orientu, i jego 132 Towarzyszy (†1785-1879) oraz 80 Męczenników XX wieku, którym przewodzi sługa Boży Franciszek Borgia Hong Yong-ho.

\section{BIBLIOGRAFIA}

ŹRODLA

CCS, Attentis conclusionibus, 29.09.2005, „Communicationes” 39 (2007), s. 56.

Codex Iuris Canonici Pii X Pontificis Maximi iussu digestus Benedicti Papae XV auctoritate promulgatus, fontium annotatione et indice analytico-alphabetico ab emo Petro Gasparri auctus, Romae: Typis Polyglottis Vaticanis 1930.

Congregatio de Causis Sanctorum, Masanensis et Aliarum. Beatificationis seu Declarationis Martyrii Servorum Dei Pauli Yun Ji-chung. Christifidelis Laici et CXXIII Sociorum in odium fidei, uti fertur, interfectorum (†1791-1888), Positio super martyrio, Roma: Tipografia Nova Res s.r.l. 2013.

FrANCISZEK, Błagamy Boga o taskę pokoju i pojednania w Korei. 18 VIII 2014 -Msza św. w seulskiej katedrze Miong-dong, LR 35 (2014), nr 8-9 (365), s. 23. 
Franciscus, Allocutio. Ad Ductores Apostolatus Laici apud Centrum Spiritualitatis in loco vulgo Kkottongnae (16.08.2014), AAS 106 (2014) 711-713; tekst w j. pol.: FrANCISZEK, Godność zarabiania na chleb powszedni. 16 VIII 2014 - Spotkanie z liderami apostolstwa świeckich w Kkottongnae, LR 35 (2014), nr 8-9 (365), s. 17-18.

Franciscus, Allocutio. Ad Episcopos Coreanos apud Sedem Coetus Episcoporum Coreanorum (14.08.2014), AAS 106 (2014) 695-700; tekst w j. pol.: FrANCISZEK, Bądźcie stróżami pamięci i nadziei. 14 VIII 2014 - Spotkanie z biskupami koreańskimi w Seulu, LR [wyd. pol.] 35 (2014), nr 8-9 (365), s. 6-8.

Franciscus, Allocutio. Ad Publicas Auctoritates Coreae Meridionalis apud Aedes Praesidiales (14.08.2014), AAS 106 (2014) 692-694; tekst w j. pol.: FRANCISZEK, W krainie spokojnego poranka. 14 VIII 2014 - Spotkanie z przedstawicielami rządu i władz państwowych w pałacu prezydenckim w Seulu, LR 35 (2014), nr 8-9 (365), s. 4-5.

Franciscus, Homilia. Ad Ductores Apostolatus apud Stadium vulgo World Cup Stadium in Coreana urbe Daejeon Eucharistiam celebrat (15.08.2014), AAS 106 (2014) 681-682; tekst w j. pol.: FrANCISZEK, Patrzymy na Maryję jako na Matkę naszej nadziei. 15 VIII 2014 - Msza św. na Stadionie Pucharu Świata w Tedzonie, LR 35 (2014), nr 8-9 (365), s. 8-9.

Franciscus, Homilia. Apud Cathedralem ecclesiam vici Myeongong Seuli Eucharistiam pro pace et concordiae reconciliatione in Corea celebratio (18.08.2014), AAS 106 (2014) 689-691; tekst w j. pol.: FrANCISZEK, Błagamy Boga o łaskę pokoju i pojednania w Korei. 18 VIII 2014 - Msza św. w seulskiej katedrze Miong-dong, LR 35 (2014), nr 8-9 (365), s. 23-24.

Franciscus, Homilia. Occasione Beatificationis CXXIV Martyrum Coreanorum apud Portam vulgo Gwanghwamun Seuli (16.08.2014), AAS 106 (2014) 683-685; tekst w j. pol.: FrANCISZEK, Dziedzictwo męczenników. 16 VIII 2014 - Msza św. w Seulu i beatyfikacja Pawła Yuna Ji-chunga i jego 123 Towarzyszy, LR 35 (2014), nr 8-9 (365), s. 13-15.

FrANCISCUS, Occasione Eucharisticae celebrationis in exitu VI Diei Asiaticae Iuventutis apud castellum urbis vulgo Haemi in Corea (17.08.2014), AAS 106 (2014) 686-688.

IOANnes Paulus II, Constitutio apostolica Divinus perfecionis Magister. Modus procedenti in Causarum canonizationis instructione recognoscitur et Sacrae Congregationis pro Causis Sanctorum nova datur ordinatio (25.01.1983), AAS 75(1983) 349-355.

IOANNES PAULUS II, Seuli, ob decretos Coreanis martyribus Sanctorum caelitum honores (6.051984), AAS 76 (1984) 990-994.

JAN PAWE⿺ II, Śmierć Męczenników stała się początkiem nowego życia. 6 maja. Homilia podczas Mszy św. na placu Yovido w Seulu, w czasie której Ojciec Święty dokonał aktu kanonizacji 103 Błogosławionych Męczenników Koreańskich, [w:] Wielkie doświadczenie Kościoła w Azji i Oceanii. 21 podróż apostolska: Korea, Papua Nowa Gwinea, Wyspy Salomona, Tajlandia, 2-11 maj 1984, Warszawa: Verbinum Wydawnictwo Księży Werbistów 1986, s. 51-54.

José SARAiva Martins, Otworzyły serca Duchowi Świętemu. 14 V 2005 - Homilia prefekta Kongregacji Spraw Kanonizacyjnych podczas Mszy św. beatyfikacyjnej, LR [wyd. pol.] 26 (2005), nr 7-8 (275), s. 6-7.

Sacra Congregatio pro Causis SAnctorum, Normae servandae in inquisitionibus ab Episcopis faciendis in causis sanctorum (7.02.1983), AAS 75 (1983) 396-403; tt. na j. pol. Henryk Misztal, w: Henryk MiszTal, Lidia FiEJDASZ-BuczeK, Postępowanie kanonizacyjne w diecezji lub eparchii, Lublin: Wydawnictwo KUL 2017, s. 259-269. 


\section{LITERATURA}

BAKER Donald: The Korean Catholic Church's first hundred years: guest editor's introduction, "Acta Koreana" 15(2012), nr 1, s. 1-14.

Catholics In Korea Activity Workbook, The History Of The Catholic Church In Korea, OptionC 2014.

Come in cielo, così in terra: Seul e i 230 anni della Chiesa Cattolica in Corea Seoul, Seoul: Archdiocese of Seoul: Seoul Museum of History 2017.

Congregatio de CAusis SAnctorum: Benedictus XIV (Prosper de Lambertinis), De Servorum Dei Beatificatione et Beatorum Canonizatione III/1, Città del Vaticano: Libreria Editrice Vaticana; Congregazione Delle CAUSE DEI SANTI: Benedetto XIV (Prospero Lambertini), La beatificazione dei Servi di Dio e la Canonizzazione dei Beati III/1, Città del Vaticano: Libreria Editrice Vaticana 2015.

Congregatio de CAusis SAnctorum: Index ac status causarum, Città del Vaticano: Libreria Editrice Vaticana 1999.

Corea, la Chiesa cattolica è la religione più stimata del Paese, http://www.asianews.it/notizieit/Corea,-la-Chiesa-cattolica-\%C3\%A8-la-religione-pi\%C3\%B9-stimata-del-Paese-35726.html

DALlET Charles: Histoire de l'Église de Corée: précédée d'une introduction sur l'histoire, les institutions, la langue, les moeurs et coutumes coréennes avec carte et planches par $\mathrm{Ch}$. Dallet Missionnaire apostolique, Société des Missions-Ėtrangères, tome premier, Paris 1874.

EBERHARD Wolfram: Symbole chińskie. Słownik, Kraków: Towarzystwo Autorów i Wydawców Prac Naukowych „Universitas” 2007, s. 255-256.

EgiguREN IRAOla Antton: True Confucians, bold Christians Korean missionary experience. A model for the third millennium, Amsterdam: Rodopi 2007.

FACCIOLI PINTOZZI Vincenzo: Giovani e martiri in Asia: la missione di Papa Francesco in Corea, prefazione di Pietro Parolin, Siena: Edizioni Cantagalli 2014.

FIEJDASZ-BuCZEK Lidia: Sprawy kanonizacyjne za pontyfikatu papieża Benedykta XVI. Studium prawno-kanoniczne, Lublin: Wydawnictwo KUL 2019.

FINCH Andrew: The Pursuit of Martyrdom in the Catholic Church in Korea before 1866, "Journal of Ecclesiastical History" 60 (2009), nr 1, s. 95-118.

HAN Hong-SOON Thomas: Corea del Sud - Vaticano. Ambasciatore Han: I 50 anni dei rapporti fra Corea e Santa Sede, l'evangelizzazione e il bene comune, http://www.asianews.it/notizie-it/ Ambasciatore-Han:-I-50-anni-dei-rapporti-fra-Corea-e-Santa-Sede,-1\%E2\%80\%99evangelizzazionee-il-bene-comune-29857.html

HwANG Alexander Y., KIM Lidia T.: The Silk Letter of Alexander Sayông Hwang Introduction and Abridged Translation, "Missiology: An International Review" 37(2009), nr 2, s. 165-179.

KAJDAŃSKI Edward: Chiny. Leksykon, Warszawa: Spółdzielnia Wydawniczo-Handlowa „Książka i Wiedza" 2011.

KIJAs Zdzisław Józef: The essentials elements of the Lord's Teaching. The Manual to transmit the Faith in Korea, „Studia Missionalia” 62(2013), s. 183-198.

KIM HeE-Joong Hyginus: On the Occasion of the 150th Anniversary of the Martyrdom during the Byeong-in Persecution, "Catholic Bishops' Conference of Korea. Newsletter" 23(2016), nr 1, s. 6

Kość Antoni: Chrześcijaństwo a kultura koreańska, „Studia Nauk Teologicznych” 5 (2010), s. 133-152.

LUHMANN F.J.: A study of the relationship between filial piety and age of urban residents in Korea and their attitude toward old people in general, DSW 1984. 
MAgister Sandro: Corea del Sud, la tigre asiatica della Chiesa, http://chiesa.espresso.repubblica.it/ articolo/1350223.html

MARTINS José Saraiva: Nowe procedury obrzędu beatyfikacji, “L'Osservatore Romano” 27 (2006), nr 3 (281), s. 42-44.

MiszTAL Henryk: Prawo kanonizacyjne. Instytucje prawa materialnego, zarys historii, procedura, Lublin: Wydawnictwo Diecezjalne w Sandomierzu 2003.

News from the Church in Korea. Opening of the Tribunal Sessions towards the Beatification of 214 Korean Martyrs, "Catholic Bishops' Conference of Korea. Newsletter 24(2017) 1, s. 7.

OGAREK-CHOI Halina: Tonghak. Nauka Wschodu, Warszawa: Iskry 1984.

Pastoral Letter on the Occasion of the 150th Anniversary of the Martyrdom during the Byeong-in Persecution, "Catholic Bishops' Conference of Korea. Newsletter" 23(2016), nr 2, s. 6-7.

RozMAn Gilbert: Can Confucianism Survive In An Age Of Universalism And Globalization?, "Pacific Affairs" 75 (2002), nr 1, s. 11-37.

The Lives of 124 Blessed Martyrs of Korea. James Zhou Wen-mo (1752-1801), “Catholic Bishops' Conference of Korea. Newsletter" 22(2015), nr 1, s. 8.

TORREY Deberniere Janet: Transcendence and anxiety in the prison letters of catholic martyr Yi Suni Ludgarda (1779-1802), "Religion \& Literature" 47(2016) 3, s. 25-55.

\section{ZAGADNIENIA WYBRANE Z PROCESU BEATYFIKACYJNEGO PAWŁA YUN JI-CHUNGA I JEGO 123 TOWARZYSZY}

Streszczenie

Myśl o rozpoczęciu procesu beatyfikacyjnego Pawła Yun Ji-chunga i jego Towarzyszy, tj. męczenników zamordowych in odium fidei w latach 1791-1888, zrodziła się jeszcze przed kanonizacją Andrzeja Kima Tae-gŏna, Pawła Chŏng Ha-sanga i 101 Towarzyszy (†1839-1868), która odbyła się 6 maja 1984 r. w Seulu. W 1997 r. Konferencja Episkopatu Korei połączyła inicjatywy kilku diecezji pod nazwą „Wspólne promowanie beatyfikacji i kanonizacji męczenników koreańskich" i przyjęła obowiązki powoda sprawy. Po uzyskaniu w 2002 r. dyspensy Kongregacji Spraw Kanonizacyjnych od normy 5a Normae servandae, jeden proces 124 męczenników zamordowanych w jedenastu diecezjach mógł przeprowadzić biskup diecezji Masan.

W prawie kanonizacyjnym zasadą jest, że zanim biskup kompetentny rozpocznie proces, podda ocenie teologicznej opublikowane pisma kandydata na ołtarze, upewniając się, czy nie znajduje się w nich nic, co sprzeciwia się wierze lub dobrym obyczajom. Ocenie teologicznej poddano dwutomowy katechizm Kościoła katolickiego Jugyo-Yoji, którego autorem był Jeong Yak-jong (1760-1801), jeden ze 124 Świadków Wiary.

W kolejnej części artykułu scharakteryzowano grupę 124 Męczenników ze względu na narodowość, stan w Kościele, płeć, wiek, status społeczny i wykonywany zawód oraz stan cywilny. Następnie scharakteryzowano prześladowcę i sposoby zadawania śmierci. Całość zamyka omówienie ceremonii beatyfikacyjnej, której osobiście przewodniczył papież Franciszek, a nie delegat Ojca Świętego (jak ma to miejsce od 2005 r.), oraz charakterystyka przesłania, jakie Kościołowi w Korei niesie beatyfikacja Pawła Yun Ji-chunga i jego 123 Towarzyszy Męczenników.

Słowa kluczowe: Kościół katolicki; Korea okresu Dynasti Chosŏn; męczennicy koreańscy; proces beatyfikacyjny; beatyfikacja; cenzura teologiczna pism; przesłanie 


\section{THE BEATIFICATION PROCESS OF PAUL YUN JI-CHUNGA \\ AND HIS 123 MARTYRS COMPANIONS. CHOSEN ASPECTS}

\section{S u m m a r y}

The first thought of initiating the beatification process of Paul Yun Ji-chunga and his companions who was martyred in period 1791-1888, was even before canonization of 103 Korean martyrs (†1839-1868). This first canonization took place on May 6, 1984 in Seoul.

In 1997 Bishops' Conference of Korea linked several diocese initiatives into a one under the name "Joint promotion for the Beatification and Canonization of Korean martyrs" and adopted the responsibilities of the Petitioner of the Cause. After obtaining the dispensation of the Congregation for the Causes of Saints from the norm 5a Normae servandae in 2002, one process of 124 martyrs murdered in 11 dioceses could have been carried out by the bishop of the Masan diocese.

In accordance with the rule of canonization law: before competent Bishop initiate the process, he evaluate published writings of the Servant of God, assuring that there is nothing in them that is against faith or good morals. Such a type of assessment was subjected to two-volume catechism of the Catholic Church of Korea Jugyo-Yoji, written by Jeong Yak-jong (1760-1801), one of the 124 Witnesses of Faith.

In the next part of this paper includes a characteristic of a group of 124 Korean martyrs under following criterion: nationality, church status, sex, age, social status, profession and marital status. Then a persecutor and ways of killing were characterised. At the end there is a description of a Beatification ceremony led by Pope Francis himself (not by his delegate as it usually happened before 2005) and characteristic of the message that the beatification of Paul Yun Ji-chung and his 123 Companions carries in the Church of Korea.

Key words: Catholic Church; Chosŏn Korea; South Korea; Korean martyrs; beatification process; beatification; theological censorship; the beatification message 